\title{
THE INTERLOCK STRUCTURE OF THE POLICY-PLANNING NETWORK AND THE RIGHT TURN IN U.S. STATE POLICY
}

\section{Val Burris}

\begin{abstract}
This paper examines interlocks among the governing boards of 12 leading policyplanning organizations and changes in the structure of this network between 1973 and 2000. Methods of multidimensional scaling and hierarchical clustering are used to construct topographical maps of the pattern of interlocks among policy-planning groups and their change over time. In contrast to the findings on corporate interlocking directorates, the study shows that board interlocks among policy-planning organizations are substantively meaningful and relatively stable at the dyadic level, although several changes in the topology of the network are also found. In all three decades, big-business "moderate-conservatives" like the Business Council and the Business Roundtable occupied the most central locations in the network. In the 1970s these organizations were linked with the "corporate liberals" to form the core cluster of the policy network. In the 1980s and 1990s the corporate liberals became relatively isolated from the core and their places were taken by several conservative groups. There was also a sharp rise in the cohesion of the network in the late 1970s and 1980s - a period that is widely seen as one of conservative political mobilization and heightened political unity among business elites. These changes in the structure of the policy network are consistent with and help to account for the rightward shift in U.S. state policy during this period.
\end{abstract}

There is an extensive literature on interlocking directorates that uses sophisticated methods of network analysis to map the structure of board interlocks among organizations and assess the implications of those interlocks for organizational behavior (Mizruchi, 1996). However, almost all of this literature — and, therefore, most of what we know about the nature and significance of interlocking directorates - is based on studies of a single type of organization: the large corporation. Like corporations, other kinds of organizations - colleges and universities, charities, civic organizations, foundations, think tanks, trade associations, political lobbies, and interest groups - also have governance structures in which professional administrators are overseen by boards of directors or boards of trustees that include members who are affiliated with outside organizations. As in the case of corporations, this governance structure creates the possibility of direct and indirect interlocks among organizations within a given domain. Unlike corporate board interlocks, however, these non-corporate networks, and their implications for organizational behavior, have received relatively little study.

This paper seeks to advance our knowledge of one type of non-corporate interlocking directorate by presenting a network analysis of the governing boards of 12 leading policy-planning organizations and changes in the structure of this interlock network between 1973 and 2000. Privately financed and directed policy-planning organizations like the American Enterprise Institute, the Brookings Institution, and the 
Council on Foreign Relations play an important role in the formation of state policy in the United States by facilitating discussion and consensus among elites, sponsoring research, lobbying government, and serving as a channel of recruitment into public service (Peschek, 1987; Smith, 1991; Dye, 2001; Domhoff, 2006). Prior research has revealed extensive interlocks among the governing boards of these organizations, but thus far the analysis of these interlocks has been mainly descriptive and limited to measuring the density of inter-organizational ties and the centrality of certain organizations or directors within this network (Domhoff, 1975; Dye, 1978; Burch, 1983; Burris, 1992). Compared with the detailed scrutiny that corporate interlocking directorates have received, our knowledge of the topology, formation, development, and implications of interlocking directorates within the policy-planning domain remains rudimentary.

In this paper I apply methods of multidimensional scaling and hierarchical clustering to construct a more detailed and visually comprehensible map of the pattern of interlocks among policy-planning groups and their change over time. These and other network analytic methods are then used to address three interrelated questions: (1) Does the degree of proximity within the interlock network accurately reflect the alignment of groups on policy issues? (2) Does the basic structure of the policy-planning network remain relatively stable despite extensive personnel changes? and (3) Are the changes in the topology of the interlock network since the 1970s substantively meaningful in terms of what is known about the policy shifts of individual organizations and the rightward tilt of the policy-planning establishment in this period? On all three questions the evidence of this study is strongly affirmative. These results illustrate the value of extending the research on interlocking directorates to include non-corporate boards of directors and also allow us to identify both commonalities and differences in the manner in which interlocks function within the corporate and the policy-planning domains.

\section{CORPORATE INTERLOCKING DIRECTORATES}

Before turning to the subject at hand, it is worth reviewing some of the main theories and findings of the research on corporate interlocks, since these will serve as points of reference for identifying the common, as well as the distinctive, features of interlocking directorates among policy-planning organizations. Several theories have been proposed to account for the formation and functioning of corporate interlocking directorates. Interlocks have been interpreted as: (1) mechanisms for the control of one firm by another or of several by some third party (Kotz, 1978); (2) manifestations of a more diffuse hegemony exercised by some types of firms over others — for example, by financial over nonfinancial firms (Mintz \& Schwartz, 1985); (3) expressions of firms’ efforts to manage uncertainty by establishing cooptive ties to other firms on which they depend for resources (Aldrich \& Pfeffer, 1976; Pfeffer \& Salancik, 1978; Burt, Christman \& Kilburn, 1980; Pennings 1980); (4) channels of communication that provide access to valued information and the prospect of coordinated action (Useem, 1984;

Mizruchi, 1992); and/or (5) reflections of the friendship networks of top corporate officers and appointments of outside board members on the basis of familiarity or the self-interest of those officers (Mace, 1971; Zajac \& Westphal, 1996). These theories are not mutually exclusive; empirical evidence can be cited to support each of them; and it is 
possible that all play some role in the formation and functioning of corporate interlocks, although not necessarily with equal weight or frequency.

Generally speaking, those theories that interpret interlocking directorates as the manifestation of some kind of distinctive relationship linking specific dyads of firms for example, a controlling or cooptive relationship that uniquely links Firm A to Firm B - have not fared well in the research on corporate interlocks. This was presaged in some of the earliest studies of corporate interlocking directorates, which showed that "broken ties" (cases in which an interlock between two firms was severed by the death or retirement of a director) were not typically restored by the exchange of a new director (Koenig, Gogel, \& Sonquist, 1979; Ornstein, 1982; Palmer, 1983). For example, one study of 1,131 large U.S. firms found that interlocks created by executives of one firm who sat on the board of a second firm were renewed only $14 \%$ of the time (Palmer, 1983). Such findings have led most researchers to conclude that the motivation and function of interlocking directorates for firms cannot ordinarily be located at the level of the specific interfirm dyad. Insofar as they are more than simply an artifact of interpersonal ties among corporate elites, corporate interlocks have thus come to be understood as a more general resource that facilitates (through any of a number of equivalent channels) the flow of communication, monitoring of events, management of uncertainty, projection of influence, or coordination of action across the larger corporate network.

Some of the most recent literature on corporate interlocking directorates adopts an agnostic stance toward any specific causal mechanism underlying the structure of board interlocks. Inspired by the so-called "new science" of networks (Barabasi, 2002; Watts, 2004), this work emphasizes the "small-world" properties that interlocking directorates share with other social, natural, or technological networks. In this view, high levels of connectivity are endemic to the intercorporate network, irrespective of the level of economic concentration, the presence or absence of coordinating institutions such as commercial banks and other financial corporations, or the strategic intent and norms governing the selection of directors (Davis, Yoo, \& Baker, 2003). So long as a few basic assumptions are met, such as the principle of preferential attachment, whereby firms or directors with the most ties are preferred as partners in the formation of new ties, the essential structure of the interlock network will remain intact. Hence, where corporate interlock networks are concerned, the typical pattern is one of volatility at the dyadic level coexisting with considerable stability at the global level.

Whatever the strategic intent underlying the creation of corporate interlocks, there is extensive evidence to show that board interlocks are associated with similarities in the choices firms make about corporate strategy and structure. Behavioral similarities among interlocked firms have been documented in such areas as a firm's propensity to engage in acquisitions (Haunschild, 1993), its response to takeover threats (Davis, 1991; Davis \& Greve, 1997), its adoption of the multidivisional form (Palmer, Jennings, \& Zhou, 1993), its reliance on bank borrowing (Mizruchi \& Stearns, 1994), its choice of which stock market to be listed on (Rao, Davis, \& Ward, 2000), and its choice of which political candidates to support (Mizruchi, 1992, Burris, 2005). This propensity for interlocked firms to adopt similar strategies and structures has been likened to a process of contagion, 
wherein board overlaps function as potent vectors for the flow of ideas and information among corporations (Davis et al., 2003).

\section{RESEARCH ON NON-CORPORATE INTERLOCKS}

Compared with the extensive literature on corporate interlocking directorates, the research on patterns of interlocking among non-corporate boards of directors is relatively sparse and largely descriptive. Most commonly, non-corporate organizations and their boards of directors are included together with corporations as part of a mixed sample that allows for the analysis of interlocks across multiple domains. For example, Salzman and Domhoff (1983) analyzed board overlaps for 1970 among 201 large corporations plus 11 foundations, 12 universities, 6 policy groups, and 7 civic and cultural organizations. They found extensive interlocking within this corporate-nonprofit network. Two policy groups (the Committee for Economic Development and the Conference Board) were among the five most central organizations and two others (the Council on Foreign Relations and the American Assembly) were among the top 25. ${ }^{1}$ Moore, Sobieraj, Whitt, Mayorova, and Beaulieu (2002) analyzed board interlocks for 1997-98 within a sample of 100 large corporations and 109 nonprofit organizations, including 50 foundations, 47 charities, and 12 policy groups. They found large corporations to be the most heavily interlocked organizations, both among themselves and across institutional sectors, whereas nonprofit organizations (with the partial exception of policy groups) were relatively marginal to the inter-organizational network. Barnes (2006) analyzed board interlocks at roughly tenyear intervals from 1962 to 1995 among approximately 250 corporations, 20 foundations, 45 cultural organizations, 30 universities, and 10 policy groups, as well as links created through directors' common membership in elite social clubs. The focus of the study was on the connectivity of the inter-corporate network and included indirect ties through noncorporate organizations only insofar as they augmented direct ties among corporations. He found that including ties formed through elite social clubs as part of the intercorporate network had a substantial effect in reducing the average distance among corporations; ties formed through policy groups had a modest effect; and ties formed through other types of nonprofit organizations had a negligible effect. ${ }^{2}$

Several studies focus more directly on policy-planning organizations, the composition of their boards, and their ties to other organizations. Not all of these studies employ formal methods of network analysis, and their findings are sometimes selective or impressionistic. For example, Dye (1978) examined the boards of trustees for 1976 of three leading policy-planning groups: the Council on Foreign Relations, the Brookings Institution, and the Committee for Economic Development. He found numerous interlocks between these organizations and the boards of large corporations, civic groups, cultural organizations, and educational institutions; however, these were not analyzed in any systematic way but were simply enumerated to illustrate Dye's theory of oligarchic tendencies in policy formation. Colwell (1980) investigated inter-organizational links for 1972 and 1975 among a sample of 27 private foundations and 31 recipient organizations, which included several of the leading policy-planning organizations. She gave only passing attention to direct ties among policy groups, focusing instead on board links between the foundation sector and the policy sector. These were particularly numerous in the case of such policy organizations as the Brookings Institution, the Council on Foreign 
Relations, the Hoover Institution, and the Committee for Economic Development. Burch (1983) examined the boards of ten major policy-planning groups at various times from the early 20th century through 1980. He identified the Business Council as the most central organization in this domain, followed by the Business Roundtable, the Council on Foreign Relations, the Committee for Economic Development, and the Trilateral Commission. Burch's concept of centrality, however, was not derived from any specific network analytic metric, but reflected his judgments about the confluence of various dimensions of connectedness, prominence, and influence. Jenkins and Eckert (2000) examined the social backgrounds and business connections of the directors of eight leading policy-planning organizations in 1980. Corporate elites dominated all eight boards, but there was also evidence of variation by industry, region, and social background among directors associated with different ideological camps. ${ }^{3}$

The first study to apply formal methods of network analysis to policy-planning organizations was by Domhoff (1975). Domhoff examined patterns of overlap among the members of 17 policy-planning groups plus 13 elite social clubs. Using a metric analogous to eigenvector centrality, he identified the Business Council as the most central organization in the club-policy network, followed by the Committee for Economic Development and the Conference Board. ${ }^{4}$ Because Domhoff's sample included the entire membership of each policy-planning organization, rather than only its governing board, and because he also included ties created through social clubs in his calculation of network centrality, his study cannot, strictly speaking, be considered a study of interlocking directorates. Nevertheless, his results are generally consistent with those of the other studies mentioned above.

To date, the most comprehensive study of interlocking directorates among policyplanning organizations is by Burris (1992). That study analyzed board interlocks among 12 policy-planning groups in 1973, 1980, and 1990. Roughly one-third of all possible dyads in the sample were directly linked in 1973, rising to more than half in 1980, then declining slightly in 1990. The "inner circle" of the policy-planning elite — defined as directors who occupied seats on two or more policy boards - was comprised primarily (more than 90\%) of the top executives of large corporations. Interlocks were generally more common among organizations that advocated a similar political ideology, although some groups had ties that spanned across ideological perspectives. The most central organizations in the network were the Business Roundtable, Business Council, and Conference Board, followed by the Committee for Economic Development, Council on Foreign Relations, and the Brookings Institution. The more conservative policy-planning organizations, such as the Heritage Foundation and the Hoover Institution, tended to occupy peripheral positions within the network, although there was evidence to suggest that one conservative policy group, the American Enterprise Institute, might be on a path toward a more central position within the network.

Pulling together the evidence from the existing literature, it is reasonable to conclude that board interlocks among policy-planning organizations are widespread and probably more prevalent than among most other types of nonprofit organizations. There is a fair degree of agreement among different studies about which organizations occupy central positions within this network in terms of connectivity. There is also agreement 
that officers and directors of large corporations are heavily represented on the boards of major policy-planning organizations. On the other hand, there is much that we do not know about interlocking directorates among policy-planning organizations. Apart from basic measures of density and centrality, very little has been done to map the topology of this interlock network in any detail. There is some evidence to suggest a tendency toward ideological homophily in the propensity to form ties among organizations, but this has not been studied systematically. The agreement among different studies conducted at different times about which organizations are most central to the network suggests a degree of stability in the overall pattern of interlocks, but the extent, form, and mechanisms producing this stability have not been documented. Finally, there is little we can say with confidence about the behavioral correlates or consequences of interlocking directorates among policy-planning organizations. Such are the issues that the present study seeks to address.

\section{THE RIGHT TURN IN U.S. STATE POLICY}

The years examined in this study overlap with what many observers describe as a period of heightened right-wing political mobilization in the United States, culminating in a sharp turn to the right in many areas of state policymaking (Edsall, 1984; Ferguson \& Rogers, 1986; Blumenthal, 1986; Clawson \& Clawson, 1987; Peschek, 1987; Vogel, 1989; Himmelstein, 1990; Akard, 1992; Allen, 1992; Jenkins \& Eckert, 2000). This right-wing mobilization is described as building momentum in the mid- and late 1970s, reaching a high-water mark in the early 1980s during the first years of the Reagan presidency, and then, after achieving many of its policy objectives, becoming routinized as an enduring but somewhat less strident and cohesive influence on policymaking from the mid-1980s onward. Among the policy changes that resulted from this political mobilization were a significant reduction in the scope of government regulation of business, a weakening of government support for environmental and consumer protection, massive tax cuts for corporations and the rich, the erection of new barriers to trade union organizing, and substantial cutbacks in social welfare spending.

According to most accounts, elite policy-planning organizations, along with the corporations, foundations, and wealthy donors that financed them, played an important role in engineering this rightward shift in U.S. state policy. As this research demonstrates, many of the initiatives that were part of the right turn in U.S. state policy were conceived, drafted, promoted, and lobbied for by privately financed and directed policy-planning organizations, and some were even implemented by government appointees recruited from the staffs of those same policy-planning groups. Some accounts of this period place considerable importance on the social networks that were cultivated in pursuit of these policy initiatives, tracing links among the political entrepreneurs who were instrumental in building some of the leading right-wing policy-planning organizations, as well as the flow of money from conservative foundations to right-wing policy groups.

Among the limitations of these studies, however, is that they have tended to focus almost exclusively on the most far right-wing policy organizations, largely ignoring the broader spectrum of established and influential policy-planning groups. And, while social networks have often been invoked as a crucial factor in explaining the right turn in U.S. 
state policy, and various forms of descriptive and anecdotal data have been marshaled to illustrate this point, little attempt has been made to apply formal methods of network analysis to the topic. In this study I take the analysis a step further, using both a broader sample of policy-planning groups and more rigorous methods of network analysis, to see whether and how the right-wing political mobilization that began in the 1970s was manifested in the topology of inter-organizational links among policy-planning groups.

\section{DATA AND METHODS}

Based on a review of the existing literature, 12 policy-planning organizations were selected as being among the most influential in the United States. These included the American Enterprise Institute, the Business Council, the Business Roundtable, the Brookings Institution, the U.S. Chamber of Commerce, the Committee for Economic Development, the Conference Board, the Council on Foreign Relations, the Heritage Foundation, the Hoover Institution, the National Association of Manufacturers, and the Trilateral Commission. ${ }^{5}$ This sample includes the same 12 organizations studied by Burris (1992) and overlaps substantially with the samples analyzed by Burch (1983), Jenkins and Eckert (2000), Moore et al. (2002), and Barnes (2006).

The primary data for this study consisted of membership lists of the governing boards of these 12 policy-planning groups, collected at roughly 5-year intervals for the years between 1973 and 2000. These years were chosen to maintain comparable samples across all years of the study. Two of the twelve organizations were founded in 1973 and one in 1972, so an analysis of years prior to 1973 would have necessitated in a truncated sample. Several policy-planning groups underwent major changes in their organizational structure around the year 2000, so an analysis that included subsequent years would have introduced incommensurabilities in the size, composition, and responsibilities of their governing boards. Similar data were collected for 2004 and 2007 and specific findings from these data will be noted (with appropriate caveats) at several points in the paper, but these years will not be included in the primary, longitudinal sample.

The Ucinet 6 software program (Borgatti, Everett, \& Freeman, 2002) was used to convert these membership lists into overlap matrices for the 12 policy-planning boards. Translating these raw overlap counts into a usable measure of the strength of overlaps among organizations posed the methodological problem of controlling for variation in the size of boards, since, ceteris paribus, organizations with large boards will tend to have more overlaps than organizations with small boards. Equivalently, a board overlap of 5 directors suggests a stronger degree of interlocking when the total size of each of the boards involved is 10 members than when it is 50 . To address this problem, I used a technique proposed by Bonacich (1972) that yields a standardized score for the degree of overlap among boards, controlling for the variation in board size. These scores range from zero to one and can be interpreted as analogous to correlation coefficients. ${ }^{6}$

The central methodological objective of the study was to render these matrices of proximities among organizations into visually comprehensible maps of the policyplanning network at different points in time. Such maps needed to be constructed in such a fashion that they provided insight into each of the three main questions I have posed for 
investigation: (1) How closely does the degree of proximity within the interlock network correspond to the alignment of groups on policy issues? (2) Does the basic structure of the policy-planning network remain relatively stable over time? and (3) What changes are evident in the topology of the interlock network across the years of the study?

The approach taken to this task was to use a combination of multi-dimensional scaling (MDS) and hierarchical clustering analysis. For economy of presentation, and to smooth year-to-year variations, the standardized interlock matrices were first aggregated by averaging scores for three years to estimate the general pattern for the decades of the 1970s, 1980s, and 1990s. In the presentation that follows, the pattern for the 1970s represents the average of the interlock scores for 1973, 1975, and 1980; the decade of the 1980s represents the average for 1980, 1985, and 1990; and the decade of the 1990s represents the average for 1990, 1995, and 2000 (see Appendix A for the complete matrices of interlock scores for these decades). The resulting interlock scores were submitted to the ALSCAL multidimensional scaling algorithm to yield a two-dimensional spatial map of the interlock network for each decade. The scores were also subjected to Johnson's (average-link) hierarchical clustering and the results superimposed on the MDS output to create a topographical map of the interlock network for each decade.

These topographical maps of the policy-planning network will serve as the primary medium for presenting the findings of the study. To complement and corroborate the visual evidence provided by these maps, I also conducted a number of supplementary analyses. To assess the tendency toward ideological homophily in the propensity to form interlocks, I constructed a measure of ideological similarity among policy organizations and computed the correlation between this measure and the strength of board overlaps. To investigate the stability of the interlock network I computed correlations among overlap matrices from one year to the next and undertook an analysis of broken ties similar to those that have been done in the case of corporate interlocking directorates. To complement the topographical analysis of changes in the interlock structure, I also measured variation in the relative centrality of individual organizations and changes in the density of overlaps across time. Finally, to provide some context for making sense of the patterns revealed through methods of network analysis, I reviewed documentary evidence on these 12 policy-planning organizations (existing case studies, press reports, official policy statements, etc.) and will draw on these sources to help clarify the underlying micro-mechanisms that are responsible for these patterns.

\section{FINDINGS}

Figures 1, 2, and 3 present topographical maps of the policy-planning network for the decades of the 1970s, 1980s, and 1990s. The placement of groups within this twodimensional space is based on a MDS algorithm that yields a solution in which the distance between any two groups is roughly proportional to the inverse of their interlock score (i.e., groups are relatively close to those with which they have the greatest board overlap and farther from those with which they have little or no overlap). Superimposed on these maps are contour lines that represent the results of a hierarchical clustering analysis. The clustering algorithm begins by joining the two groups with the highest interlock score, which it then treats as a single entity with a new profile of interlock 


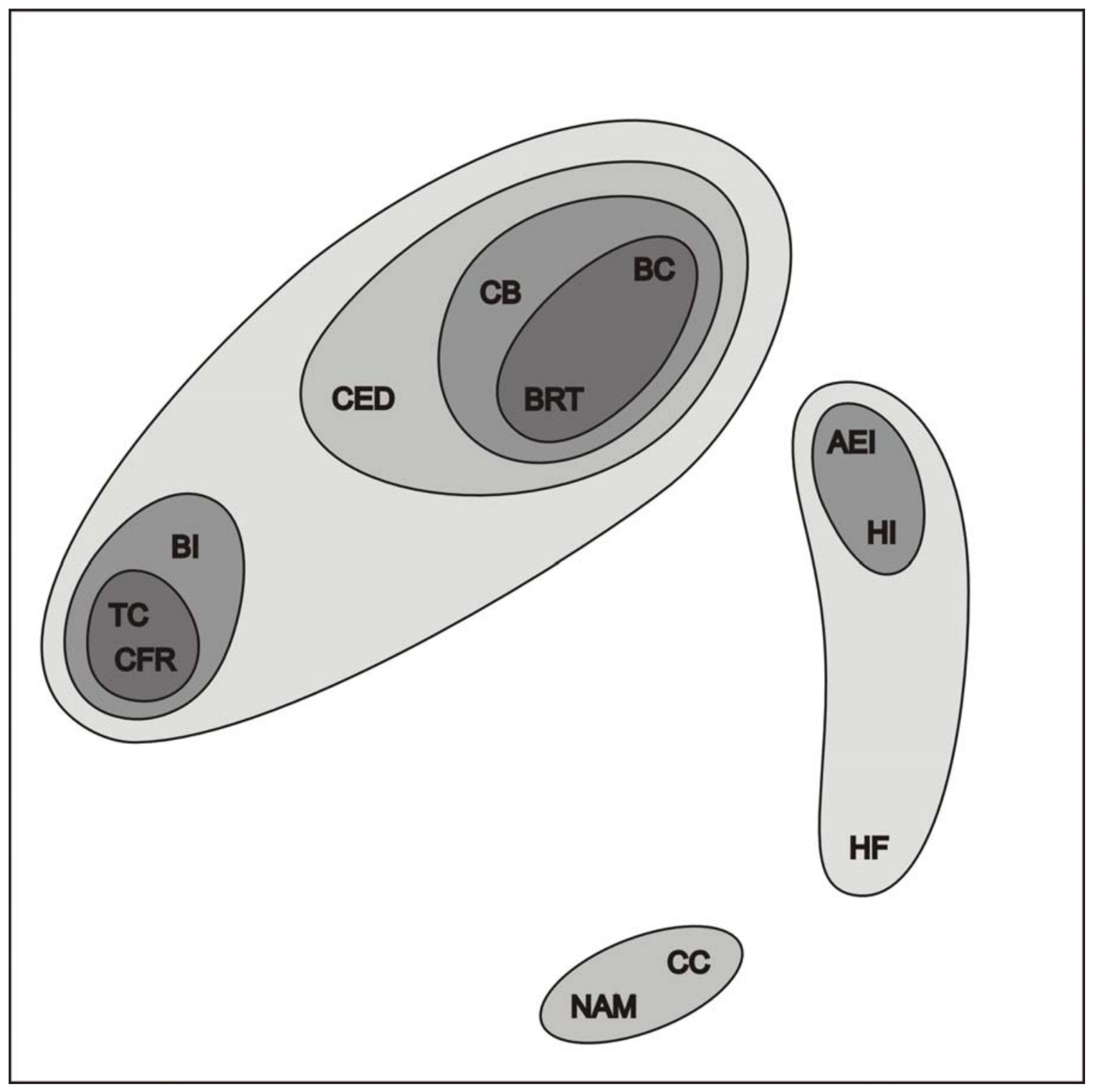

Key: $\mathbf{A E I}=$ American Enterprise Institute; $\mathbf{B C}=$ Business Council $\mathbf{B I}=$ Brookings Institution; $\mathbf{B R T}=$ Business Roundtable; CB = Conference Board; $\mathbf{C C}=$ Chamber of Commerce; $\mathbf{C E D}=$ Committee for Economic Development; CFR = Council on Foreign Relations; HF = Heritage Foundation; $\mathbf{H I}=$ Hoover Institution; NAM = National Association of Manufacturers; TC = Trilateral Commission.

Fig. 1. Policy-Planning Clusters in the 1970s 


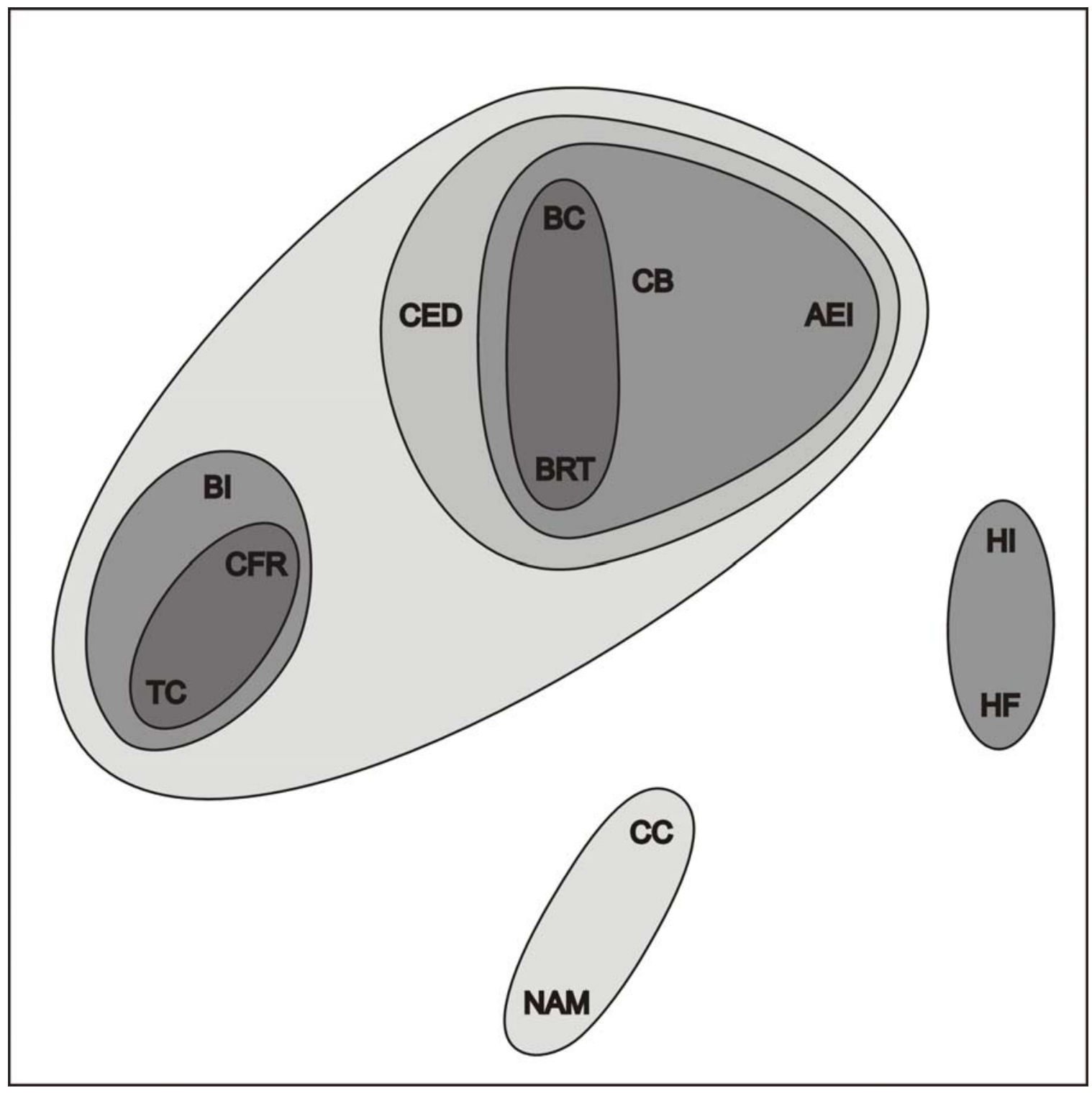

Key: $\mathbf{A E I}=$ American Enterprise Institute $\mathbf{B C}=$ Business Council; $\mathbf{B I}=$ Brookings Institution; $\mathbf{B R T}=$ Business Roundtable; $\mathbf{C B}=$ Conference Board; $\mathbf{C C}=$ Chamber of Commerce; $\mathbf{C E D}=$ Committee for Economic Development; CFR = Council on Foreign Relations; HF = Heritage Foundation; HI = Hoover Institution; NAM = National Association of Manufacturers; TC = Trilateral Commission.

Fig. 2. Policy-Planning Clusters in the 1980s 

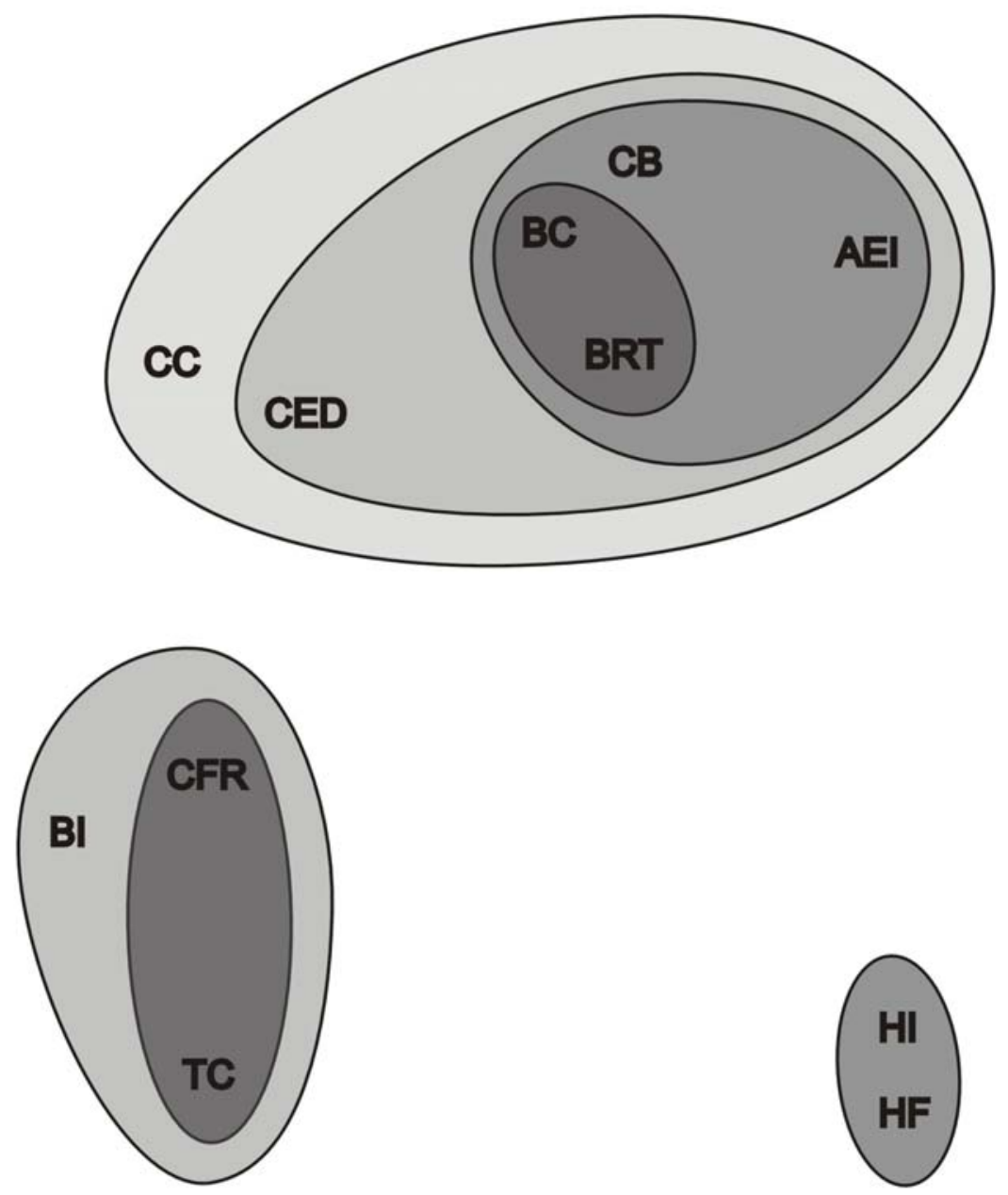

\section{NAM}

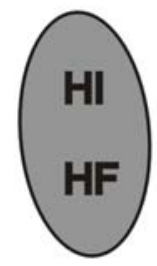

Key: $\mathbf{A E I}=$ American Enterprise Institute; $\mathbf{B C}=$ Business Council; $\mathbf{B I}=$ Brookings Institution; $\mathbf{B R T}=$ Business Roundtable; $\mathbf{C B}=$ Conference Board; $\mathbf{C C}=$ Chamber of Commerce; $\mathbf{C E D}=$ Committee for Economic Development; CFR = Council on Foreign Relations; HF = Heritage Foundation; $\mathbf{H I}=$ Hoover Institution; NAM = National Association of Manufacturers; TC = Trilateral Commission.

Fig. 3. Policy-Planning Clusters in the 1990s 
scores equal to the average of its members. This process is then repeated until all groups have been assigned to a cluster and all clusters have been consolidated into larger ones, or until a point is reached at which no further clusters are possible that meet a minimum threshold of connectivity (see Appendix B for the complete results of the hierarchical clustering analysis). The darkness of shading within each contour line is roughly comparable within and across the three maps, so that a given density of gray represents a roughly equivalent strength of interlocks within each cluster.

\section{Ideological Homophily}

The first issue I wish to explore is the tendency toward ideological homophily in the formation of interlocks among policy-planning organizations. There are several reasons to expect interlocks to be more common among dyads of organizations that advocate generally similar ideological positions. From the literature on corporate interlocking directorates we know the value that interlocks can have in providing channels of communication and facilitating coordinated action — functions that would seem to be most useful in the case of organizations committed to common political goals. To the extent that ideological criteria are operative in the selection of directors, we would also expect ideologically similar organizations to draw from a common pool of potential directors, thereby increasing the likelihood of board overlaps. Dependence on common sources of funding may also bring with it a shared interest or obligation to appoint some of the same individuals to directorships. On the other hand, it is also the case that policyplanning organizations, like both corporations and other nonprofit organizations, must complete for resources and recognition, and this competition is often most heated among organizations that are seeking to fill roughly similar niches with respect to the product or service they are marketing. Such competition could easily result in a desire to steer clear of board entanglements with ideologically similar rivals. Moreover, for reasons of political connections, access to information, and public legitimacy, policy-planning organizations, no less than corporations, have an interest in board diversity that runs contrary to any predisposition to homophily in the selection of directors. Hence, while there are good reasons to expect a degree of ideological homophily in the formation of board interlocks among policy-planning organizations, the strength of this tendency and its consequences for the overall structure of the interlock network remain to be shown.

The literature on policy-planning organizations commonly distinguishes between two broad ideological groupings (Burris, 1992; Domhoff, 2006). I shall refer to these as the "moderate-conservative" bloc and the "ultraconservative" bloc. In the first camp would be placed the Brookings Institution, Committee for Economic Development, Conference Board, Council on Foreign Relations, Trilateral Commission, Business Council, and Business Roundtable. In the second camp would be placed the American Enterprise Institute, Heritage Foundation, Hoover Institution, U.S. Chamber of Commerce, and National Association of Manufacturers. ${ }^{7}$

This simple dichotomy fails to capture many of the nuances of ideological alignment within the policy-planning network. For example, within the moderateconservative bloc, the Trilateral Commission, Brookings Institution, Council on Foreign Relations, and Committee for Economic Development would be considered by most 
observers to be somewhat closer to the liberal end of the political spectrum than the Business Council, Business Roundtable, and Conference Board. Within the ultraconservative bloc there are two organizations - the U.S. Chamber of Commerce and National Association of Manufacturers - whose conservatism has a distinctive character because of its historic association with small-business interests. Both of these organizations date from the pre-WWI period and have long been concerned primarily with trade and labor issues. The other organizations of the ultraconservative bloc are either newly formed (as in the case of the Heritage Foundation, founded in 1973) or were revived from relative obscurity by an infusion of corporate and right-wing foundation support in the 1970s (as in the case of the American Enterprise Institute and Hoover Institution). These three organizations are commonly associated with the rise of the New Right in the 1970s and 1980s, and, as such, espouse a policy agenda that blends economic conservatism with a commitment to "traditional values" and hard-line foreign policy.

Turning to Figure 1, it is evident that ideological homophily played a strong role in shaping the topology of the policy-planning network in the 1970s. As an illustration, if one were to draw a diagonal line from the lower-left corner to the upper-right corner of the map, all seven moderate-conservative policy groups would be found on one side of that line and all five ultraconservative groups would be found on the other side. Looking more closely at particular clusters, we see that all three of the organizations associated with the New Right — the Heritage Foundation, Hoover Institution, and the (slightly more centrist) American Enterprise Institute - are clustered at the right end of the horizontal axis. At the left end of the horizontal axis are three of the more liberal of the moderate-conservative policy organizations: the Trilateral Commission, Brookings Institution, and Council on Foreign Relations. Henceforth, I shall refer to these three organizations as the "corporate liberal" cluster of the policy-planning establishment. ${ }^{8}$ At the lower end of the vertical axis are the small-business ultraconservatives: the National Association of Manufacturers and U. S. Chamber of Commerce. And near the top of the vertical axis are the rest of the big-business-dominated moderate-conservatives: the Business Council, Business Roundtable, Conference Board, and Committee for Economic Development. These four organizations constitute not only the most centrally located cluster in terms of interlocks, but also the most politically centrist with respect to the (admittedly truncated) spectrum of ideological perspectives represented in the sample. I shall turn shortly to a closer examination of the topographical maps for the 1980s and 1990s, but suffice to say that the policy-planning network in these decades also exhibits a pronounced tendency toward clustering on the basis of ideological homophily.

As a check on the robustness of the patterns revealed by visual inspection of the MDS and clustering results, I also conducted a simple statistical test of the association between network proximity and ideological affinity. One should rightly be wary of any measure that seeks to reduce the ideological diversity among policy-planning organizations to scores or rankings along a single left-right continuum; nevertheless, there is precedent for such a measure in the analyses conducted by political interest groups. Specifically, just as activist groups sometimes create scorecards of candidates' voting records, there is one organization, the Capital Research Center (CRC), that creates scorecards of corporations' records of charitable giving, including their contributions to nonprofit policy-planning groups. This is done by assigning each nonprofit organization 
a score on a scale from 1 ("radical left") to 8 ("market right") and averaging the scores of each company's grant recipients, weighted by the size of the individual grants (Yablonski, 2001). The Capital Research Center is, itself, a very conservative organization, whose primary mission is to expose and castigate corporations for not contributing more to other conservative organizations, so there is a tendency for them to exaggerate the "liberal bias" of corporate philanthropy by applying left-wing labels to fairly mainstream groups. Nevertheless, the relative rankings that they assign to nonprofit organizations are reasonably consistent with what I take to be the consensus of informed opinion on the subject. For example, of the 12 policy-planning groups in this sample, the CRC gave the lowest scores of 3 or 4 to the Trilateral Commission, Brookings Institution, Council on Foreign Relations, and Committee for Economic Development, and the highest scores of 7 or 8 to the Heritage Foundation, Hoover Institution, and American Enterprise Institute.

The chief limitation of the CRC data is that they include only organizations that are eligible to receive tax-deductible contributions or that have affiliates that are eligible for tax-deductible contributions. This omits three major policy-planning groups: the Business Council, Business Roundtable, and Conference Board. Based on what I take to be the consensus of the literature, I assigned all three of these groups an ideological rating of 5, which placed them just to the "left" of the small-business ultraconservativess (the Chamber of Commerce and National Association of Manufacturers), both of which received a CRC rating of 6 , and just to the right of the reputedly more liberal of the moderate-conservative organizations like the Brookings Institution and the Council on Foreign Relations, which received a CRC rating of 4.

Using these augmented CRC rankings, I constructed a measure of the ideological distance between policy-planning organizations by simply taking the absolute difference in the rankings of the two organizations in each dyad. Subtracting these results from the maximum difference of five yielded a measure of ideological proximity that ranges from zero to five. I then computed correlations (using the QAP algorithm in Ucinet 6) between this matrix of ideological proximity and the matrices representing the strength of interorganizational interlocks for the 1970s, 1980s, and 1990s. The resulting correlations coefficients were $r=0.522,0.539$, and 0.500 respectively ( $p<0.001$ in all cases). ${ }^{9}$ Considering the unidimensionality and limited variance of the measure of ideological proximity, this is an impressive result and shows that, despite potentially countervailing tendencies, ideological homophily is a powerful force in shaping the structure of the policy-planning network. The strong association between ideological affinity and network proximity further suggests that director interlocks may often play an important role in cementing political alliances and coordinating activities among like-minded policy-planning organizations.

\section{Network Stability}

As noted earlier, such stability as exists among corporate interlocking directorates is found mainly at the structural or global level, rather than the dyadic level. For example, basic structural parameters of corporate networks, such as network density, the average number of interlocks per firm, the average geodesic distance between firms, and the 
propensity toward clustering, remain relatively stable across decades, while, at the dyadic level, what specific firms link to what other specific firms is in constant flux (Davis et al., 2003). Among the clearest evidence of the volatility of corporate networks at the dyadic level are studies that show the relative infrequency with which broken ties created by the death or retirement of a director are restored by a new tie to the same firm (Koenig et al., 1979; Ornstein, 1982; Palmer, 1983).

By comparison, the policy-planning network displays considerable stability at the level of individual dyads. This can be seen by noting the consistency across decades in the topographical maps of the policy-planning network. With only a few exceptions, those dyads of policy organizations that tend to be most proximate to one another in the 1970 s (i.e., those that share the strongest degree of overlap among their boards) tend to be most proximate in the 1980s and 1990s as well. To confirm the visual evidence provided by the MDS and clustering analysis, I also computed correlations from one decade to the next for the interlock scores assigned to each dyad of policy-planning groups. The results were $r=0.574(p<0.001)$ for the dyadic similarity between 1973 and 1980, $r=0.670$ $(p<0.001)$ for the dyadic similarity between 1980 and 1990, and $r=0.556(p<0.001)$ for the dyadic similarity between 1990 and $2000 .^{10}$

The dyadic stability of the policy-planning network is not explained by any tendency for policy-planning directors to remain in their board positions for an extended period of years. Indeed, given the fact that service on policy-planning boards is typically unpaid and tangential to most directors' primary career, policy-planning directors tend to serve relatively short terms. ${ }^{11}$ Over the span of a decade, the turnover among policyplanning directors is roughly $80 \%$. With respect to interlocks, of the 88 total interlocks (counting multiple ties) linking policy groups in 1980, only 12 (14\%) were created by directors who had held those same positions in 1973; of the 81 total interlocks in 1990, only 7 (9\%) were created by directors who had held those same positions in 1980; and of the 52 total interlocks in 2000, only 2 (4\%) were created by directors who had held those same positions in 1990.

To get a better sense of the strength of dyadic stability in the policy-planning network, I conducted a broken-tie analysis similar to those that have been done previously on corporate interlocking directorates. For the purpose of identifying broken ties, I chose the years of 1980 and 1990 as the focus of the analysis. These years were chosen for several reasons. With the limited number of ties that are possible in a network of only 12 organizations, I needed a long enough time span to yield a sufficient number of broken ties for analysis, and I found that a 10-year period satisfied this need. I also wanted to compare two years for which the overall number of ties was relatively constant (or, ideally, slightly declining) so that any tendency toward the reconstitution of broken ties could not be attributed to the random effects of an increase in the total number of ties. The years of 1980 and 1990 also satisfied this requirement. The basic method and nomenclature for classifying broken ties are taken from Palmer (1983), and comparisons will be made between the results of this analysis and his study of broken ties among corporate boards of directors.

Of the inter-organizational dyads that were linked in 1980, 32 of those ties were broken over the coming decade in the sense that all of the directors who formed those ties 
departed from one or both of the boards they previously linked (see Table 1). Another three ties were disrupted or reduced in strength in the sense that some, but not all, of the directors linking that dyad of organizations departed. Of these 35 broken or disrupted ties, 23 (66\%) were reconstituted through the appointment of new interlocking directors; 1 (3\%) was maintained at a lower strength without adding new interlocks, and 11 (31\%) were discontinued and the organizations ceased to be linked. Comparable figures for broken or disrupted ties among corporate boards are roughly 15\% reconstituted, 19\% maintained, and 66\% discontinued (Palmer, 1983, p. 48).

Table 1. Broken Ties Among Policy-Planning Organizations, 1980-90

\begin{tabular}{|c|c|c|c|c|}
\hline \multicolumn{5}{|c|}{ Total Ties } \\
\hline Broken & Disrupted & Reconstituted & Maintained & Discontinued \\
\hline \multirow[t]{2}{*}{32} & 3 & 23 & 1 & 11 \\
\hline & \multicolumn{3}{|c|}{ Single Ties Only } & \\
\hline Broken & Disrupted & Reconstituted & Maintained & Discontinued \\
\hline \multirow[t]{2}{*}{17} & - & 8 & - & 9 \\
\hline & \multicolumn{3}{|c|}{ Multiple Ties Only } & \\
\hline Broken & Disrupted & Reconstituted & Maintained & Discontinued \\
\hline 15 & 3 & 15 & 1 & 2 \\
\hline
\end{tabular}

The rate of broken-tie reconstitution among policy-planning boards is thus several magnitudes higher than among corporate boards. One pattern that is similar across the two institutional domains is that multiple ties (interlocks of more than a single director) are more likely to be reconstituted than single ties. Among policy-planning boards, the reconstitution rate is approximately $83 \%$ for multiple ties and $53 \%$ for single ties. Comparable figures for corporate boards are $24 \%$ for multiple ties and $9 \%$ for single ties (Palmer 1983, p. 48). In the case of corporate interlocks, such findings have been interpreted as evidence that multiple ties are more likely to reflect a substantively meaningful dyadic relationship of control, cooptation, or coordination that gives one or both parties an incentive to restore the tie when it is broken or weakened, whereas single ties are more likely to be coincidental. Whether the same logic applies to policy-planning interlocks cannot be proven with these data, although the hypothesis is certainly plausible. $^{12}$ 


\section{Changes in the Structure of the Interlock Network}

The changes in the interlock network between the 1970s and the 1990s were modest but nonetheless significant. As shown in Figure 1, there were three main clusters in the 1970s. The core cluster included two sub-groups: the big-business moderateconservatives (Business Council, Business Roundtable, Committee for Economic Development, and Conference Board) and the corporate liberals (Brookings Institution, Council on Foreign Relations, and Trilateral Commission). The New Right ultraconservatives (American Enterprise Institute, Heritage Foundation, and Hoover Institution) and the small-business ultraconservatives (U.S. Chamber of Commerce and National Association of Manufacturers) each formed a smaller, isolated cluster. In the 1980s (Figure 2) there was one notable change: the American Enterprise Institute, one of the more centrist of the New Right policy-planning groups, moved into the core cluster where it became closely aligned with the big-business moderate-conservatives. In the 1990s (Figure 3) there were two further changes: the corporate liberals became relatively isolated from the core cluster and their place was taken by the entry of a second ultraconservative group - the historically small-business-oriented U.S. Chamber of Commerce. In sum, the trend from the 1970s to the 1990s was one of the progressive marginalization of the corporate liberal cluster, matched by the selective inclusion of members of the previously marginal ultraconservative clusters into a closer alignment with the core group of big-business moderate-conservatives.

The realignment of groups between the core and the periphery of the policyplanning network can also be seen in the changes in the relative centrality scores for different organizations. To calculate centrality scores I used a factor-analytic technique proposed by Bonacich (1972), which is to take the first principle component of the matrix of standardized overlaps among organizations. This measure is equivalent to an eigenvector centrality metric in the sense that the links of each organization are weighted by the centrality of the other organizations to which it is connected. For ease of interpretation, I normalized these scores by dividing by the mean centrality score for each year, so that, for example, a score of 1.5 represents a centrality of one and a half times the average for that year, while a score of 0.5 represents a centrality of half the average. These scores are shown in Table 2. Policy-planning organizations have been grouped into moderate-conservative and ultraconservative categories, and, within categories, are listed from the more central to the less central organizations.

These centrality scores replicate many of the patterns we have already seen in the topographical maps of the policy-planning network, but they provide more precision with respect to the timing and magnitude of shifts in the relative connectedness of individual organizations. Within the moderate-conservative category, the Business Roundtable and Business Council are the most central organizations throughout the entire period of the study. The Conference Board and Committee for Economic Development follow close behind, with only a slight drop-off in their centrality in the year 2000. As a group, the organizations I have referred to as the "corporate liberals" are less central, although the Council on Foreign Relations and Brookings Institution are still above the mean in most years. The Trilateral Commission is by far the most peripheral of the corporate-liberal policy groups, and (as shown in Appendix A) is connected to the larger network mainly 
through its strong ties to the CFR and Brookings. It is also evident from these data that the increasing isolation of the corporate liberals from the core cluster of big-business moderate-conservatives from the 1980s to the 1990s was mainly due to a decline in the connectivity of Brookings and Trilateral that was not shared by the Council on Foreign Relations, which retained strong ties throughout this period. Hence it might be more accurate to say that Brookings and Trilateral, rather than corporate liberals as a whole, became relatively isolated from the core cluster of moderate-conservative groups.

Table 2. Normalized Centrality Scores of Policy-Planning Organizations

\begin{tabular}{lccccccc}
\hline & 1973 & 1975 & 1980 & 1985 & 1990 & 1995 & 2000 \\
\hline & & & & & & & \\
Moderate-Conservatives & & & & & & & \\
Business Roundtable & 1.64 & 1.65 & 1.69 & 1.60 & 1.63 & 2.14 & 2.51 \\
Business Council & 1.66 & 1.48 & 1.32 & 1.72 & 1.75 & 1.87 & 2.08 \\
Conference Board & 1.74 & 1.55 & 1.38 & 1.46 & 1.41 & 1.32 & 0.81 \\
Committee for Econ. Develop. & 1.63 & 1.42 & 1.07 & 1.30 & 1.41 & 1.17 & 0.65 \\
Council on Foreign Relations & 0.83 & 0.99 & 0.92 & 1.32 & 1.54 & 1.66 & 1.31 \\
Brookings Institution & 1.08 & 1.20 & 1.22 & 1.00 & 1.05 & 0.78 & 0.64 \\
Trilateral Commission & 0.98 & 0.99 & 0.87 & 0.50 & 0.50 & 0.57 & 0.64 \\
& & & & & & & \\
Ultraconservatives & & & & & & & \\
American Enterprise Inst. & 0.65 & 0.84 & 1.23 & 1.44 & 1.28 & 1.03 & 1.51 \\
Chamber of Commerce & 0.43 & 0.50 & 0.79 & 0.70 & 0.70 & 0.51 & 1.17 \\
Hoover Institution & 1.14 & 0.85 & 0.60 & 0.54 & 0.46 & 0.42 & 0.00 \\
Nat'l Assoc. of Manufacturers & 0.23 & 0.23 & 0.29 & 0.25 & 0.18 & 0.41 & 0.67 \\
Heritage Foundation & 0.00 & 0.29 & 0.60 & 0.20 & 0.10 & 0.12 & 0.00 \\
& & & & & & & \\
\hline
\end{tabular}

Within the ultraconservative category, the movement of the American Enterprise Institute from the periphery to a central position within the network is clearly shown in the sharp increase in its centrality between 1975 and 1980. The subsequent shift of the Chamber of Commerce toward the core of the network is less dramatic and confined mainly to a sharp rise in its centrality between 1995 and $2000{ }^{13}$ The other ultraconservative organizations are consistently peripheral to the network, with the exception of a brief period in the early 1970s when the Hoover Institution had centrality scores that were roughly equal to the mean.

One significant change in the structure of the policy-planning network that is not immediately evident in the results of the MDS and clustering analysis is the variability in 
the overall density of the network over the three decades of the study. This variability is illustrated in Figure 4, which graphs the rise and fall of three different measures of network density: the proportion of binary ties (i.e., the proportion of all dyads that are linked by one or more shared director); the ratio of all ties (counting multiple ties) to the total number of dyads; and the average centrality score. Regardless of the measure employed, the pattern is roughly the same. There is a sharp increase in the density of interlocks between 1975 and 1980; the density of the network remains relatively high throughout the 1980s; then there is a marked decline in network density during the decade of the 1990s. ${ }^{14}$ Data for 2004 and 2007, although not strictly comparable because of changes in the governance structures of several policy-planning groups, suggest that the density of the interlock network has not risen appreciably in the years since 2000.

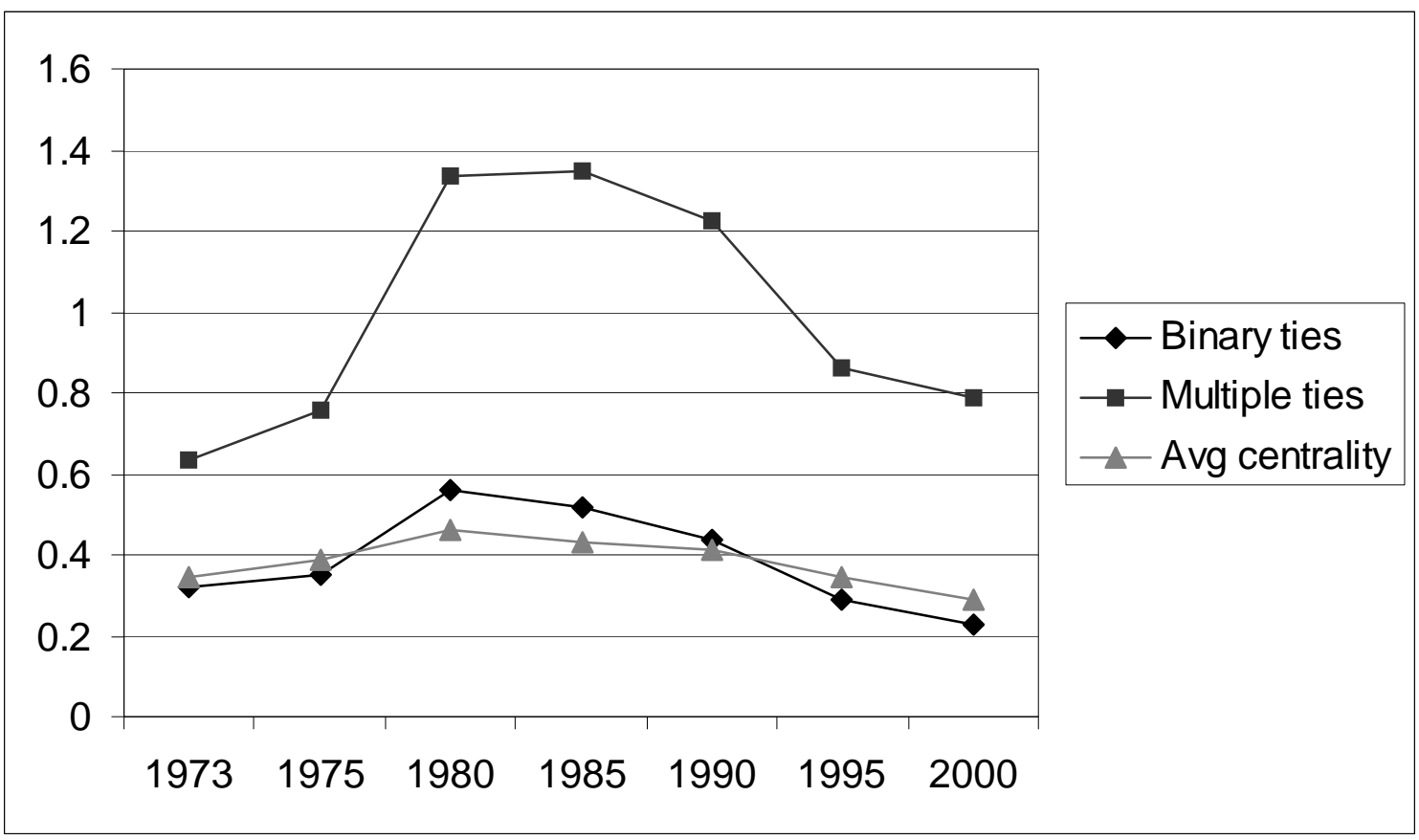

Fig. 4. Density of the Policy-Planning Network

In sum, despite considerable stability in the structure of the policy-planning network, there were two notable changes that occurred during this period: (1) there was a modest, but significant, realignment whereby several, once marginal, ultraconservative organizations moved toward the central core of the network, while some of the more liberal organizations moved toward the periphery; and (2) there was a sharp increase in the density of interlocks from the mid-1970s through the 1980s, followed by a decline in the 1990s. Although the mechanisms underlying these changes remain to be clarified, there are obvious parallels between these changes in the structure of the policy-planning network and narrative accounts of the late 1970s and early 1980s that describe this as a period of heightened political mobilization and increased political unity among economic elites (hence the increase in network cohesion), resulting in a significant rightward turn in state policy (hence the more central positions occupied by right-wing policy groups). 


\section{INTERPRETATION AND HISTORICAL CONTEXT}

At the outset of the paper I raised three questions for analysis: (1) Does the degree of proximity within the interlock network accurately reflect the alignment of groups on policy issues? (2) Does the basic structure of the interlock network remain relatively stable despite extensive personnel changes? and (3) Are the changes in the topology of the network since the 1970s substantively meaningful in terms of what is known about the policy shifts of individual organizations and the general rightward turn in U.S. state policy during this period? I now return to each of these questions to summarize what has been learned, to explore the possible interpretations of these findings, and to contextualize the results of the study in relation to the more qualitative evidence on policy-planning organizations.

\section{Network Stability}

Let me begin with the question of network stability. As a rough approximation, one might say that the pattern for the policy-planning network is nearly the opposite of what has been found in the research on corporate interlocking directorates. Specifically, corporate interlocks tend to be highly volatile at the dyadic level, while remaining quite stable in terms of their global structure; whereas, policy-planning interlocks are mostly stable at the dyadic level, while exhibiting a moderate degree of variability in such global properties as network density. This suggests that, of the different theories that have been proposed to account for interlocking directorates, the plausibility or salience of various accounts of the motives or functions of interlocks are very different for policy networks than they are for corporate networks. Theories that appear to have limited applicability to corporate networks, such as those that hypothesize a distinctive relationship of control, cooptation, or coordination linking specific dyads of organizations, are more consistent with the pattern of policy-planning interlocks. On the other hand, theories that interpret interlocks as nothing more than an artifact of the personal networks of organizational elites or a manifestation of universal properties that are common to all networks do not fit well with either the dyadic stability or the global variability of policy-planning networks.

\section{Ideological Homophily}

Among the factors that sustain dyadic stability within the policy-planning network, the propensity toward ideological homophily in the formation of interlocks would appear to be an important cause. One of the strongest findings of this study is the near perfect match that it reveals between the proximity of policy groups, as shown in the topographical maps of their interlocks, and recognized political alignments and cleavages

within the policy-planning network. ${ }^{15}$ In other words, what this study demonstrates is the close correspondence between qualitative assessments of ideological alignments among policy groups and quantitative measures of their proximity based on board interlock data.

With respect to the mechanisms producing ideological homophily, there are certainly instances in which the formation of interlocks among ideologically similar policy groups is simply a result of the independent application of similar screening criteria in the selection of directors by ideologically kindred organizations. There are 
numerous cases, however, in which the formation of such ties is clearly the manifestation of an overt inter-organizational relationship of control, cooptation, or coordination. For example, as previous research has shown, ideologically similar policy groups often share common sources of funding (Allen, 1992; Covington, 1997). Close inspection of the interlocks between specific dyads of policy groups reveals numerous instances in which ideologically similar policy organizations are linked by common directors representing these shared funding sources, including both individual capitalist donors and the officers or directors of corporate and foundation donors. A good example would be the strong

and persistent linkage between the Hoover Institution and the Heritage Foundation, which has been perpetuated over the years by the overlapping membership on their boards of such major right-wing donors as Joseph Coors, Richard Mellon Scaife, Shelby Cullom Davis, Robert H. Krieble, and William E. Simon. In these cases, interlocks between Heritage and Hoover can be viewed as an expression of their common obligation toward, oversight by, or interest in coopting directors who are vital to their financial well-being.

In other cases, board interlocks among ideologically similar organizations coincide with a formally institutionalized partnership in pursuit of a common policy agenda. A good example would be the U.S. Chamber of Commerce and the National Association of Manufacturers, which have often maintained joint bodies for conducting policy discussion and lobbying activities, and even sought (unsuccessfully) to negotiate a merger of their separate organizations in the mid-1970s (Levitan \& Cooper, 1984). Director interlocks in such cases can be viewed both as a facilitating factor and as an outgrowth of an extended history of formal inter-organizational cooperation. ${ }^{16}$

In still other cases, the relationship between ideologically kindred policy groups is similar to that of a parent company and its subsidiary, in which case board overlaps can be viewed as a sign of the tutelage of the junior partner in the relationship. For example, the Trilateral Commission was founded in 1973 by David Rockefeller, then chairman of the Council on Foreign Relations, with support from the CFR and the Rockefeller Foundation. Thirty years later, the umbilical cord between the two organizations remains intact and the Trilateral Commission's strongest interlocks are still with the CFR.

\section{Changes in the Structure of the Interlock Network}

Turning to the question of changes in the structure of the policy-planning network, two organizations stand out as having undergone the most significant shifts in their pattern of interlocks: the American Enterprise Institute and the U.S. Chamber of Commerce. In both cases, one can find evidence in the histories of these organizations to suggest that these shifts coincided with broader changes in the orientation, activities, and affiliations of these policy groups.

The American Enterprise Institute's rise to prominence in the 1970s and 1980s has already received extensive attention in the qualitatively oriented literature (Peschek, 1987; Blumenthal, 1986; Smith, 1991). As recently as 1970, the AEI commanded few resources and received little public attention. During the 1970s, however, several events helped to catapult the AEI from the margins to the center of the policy-planning network. A generous grant from the Ford Foundation in the early 1970s significantly enhanced the 
legitimacy of the organization. The Business Roundtable, which was founded in 1972, made the strengthening of the AEI one of its top priorities. Then, following the 1976 election, former President Gerald Ford became a fellow at the AEI, bringing with him a retinue of conservative advisors from the Nixon/Ford administration and committing himself to assist in the organization's fundraising. With the endorsement of former President Ford and support from business leaders associated with the Business Roundtable, the AEI launched a development campaign in 1978 to raise a \$60 million endowment, mainly from large corporations. The campaign had the effect of dramatically increasing the AEI's budget and scale of operations, as well as shifting the source of its funding from a handful of right-wing foundations to the broader corporate community.

While the rise of the American Enterprise Institute has been recounted numerous times in narrative terms, what this study shows is that the increasing prominence of the organization was accompanied by an equally dramatic (and quantitatively measurable) shift in the pattern of its interlocks. In 1973 and 1975, the AEI's strongest interlocks were with the ultraconservative Hoover Institution. The AEI's board included only a few CEOs of large corporations, mainly from the South or West, only one of whom (Miami banker and CED director Harry Hood Bassett) created a link to any of the policy groups of the moderate-conservative core. By 1980 the AEI board included no less than five of the most influential board members of the Business Roundtable, including Roundtable co-chairman Walter Wriston of Citicorp, Robert Hatfield of Continental Group, David Packard of Hewlett-Packard, Richard Shinn of Metropolitan Life, and Richard Wood of Eli Lilly. Collectively these five corporate leaders also held three seats on the board of the Business Council, two on the Committee for Economic Development, and one on the Conference Board. Although AEI retained three board overlaps in 1980 with Hoover and one with Heritage, its interlocks had shifted decisively toward an alignment with the moderate-conservative core of the policy-planning network and away from an exclusive affiliation with the ultraconservative bloc — a pattern that remains stable to the present day. Accompanying this realignment has been what most observers would describe as a modest shift of the AEI toward the political center, although that shift is arguably better described as the adoption of a more scholarly and less dogmatic style of policy analysis than an abandonment of any of the core principles of the political Right.

The second organization to undergo a noticeable shift in its position within the policy-planning network is the U.S. Chamber of Commerce. Like the AEI before it, the U.S. Chamber of Commerce has followed a path from the ultraconservative margins of the interlock network toward the moderate-conservative core. The change here is not so dramatic and it is sufficiently recent that its longevity remains to be seen, although the available evidence suggests that it has persisted through 2007.

To understand the context and possible reasons for this shift, it is instructive to compare the Chamber of Commerce with its long-time ally, the National Association of Manufacturers. Since their founding, both organizations have had memberships in which small and medium-sized businesses predominated, and, for much of their history, both have maintained, at best, an uneasy alliance with the big-business-dominated policy organizations of the moderate-conservative core. Part of this can be explained by the more pronounced antipathy that smaller businesses traditionally have exhibited toward 
compromise on matters of collective bargaining or government regulation; however, a further factor has been the staunch protectionism that both organizations have espoused until recently. Among the main issues that historically have divided small and mediumsized domestic businesses from large banks and multinational corporations has been the question of free trade. In the post-WWII era, big corporations have mostly tended to support trade liberalization, even though fissures have often emerged between importand export-competitive industries, whereas smaller businesses have been much more consistently protectionist, having much more to lose from increased imports than they are likely to gain from increased exports.

As early as the 1930s, big business representatives began to make inroads into the leadership of NAM and the Chamber of Commerce, but their control was far from complete and, initially, they had little impact on the protectionist proclivities of these organizations. For example, both NAM and the Chamber of Commerce were unenthusiastic about President Kennedy's efforts to liberalize American trade policy in the 1960s, with NAM taking no official position because of internal divisions and the Chamber of Commerce, after heated debate, providing only qualified support with many dissenting opinions. Corporate support for Kennedy’s initiatives came mainly from business leaders associated with moderate-conservative policy organizations like the Committee for Economic Development, the Brookings Institution, and the Council on Foreign Relations (Zeiler, 1992). This pattern continued through the mid-1980s, as rising trade deficits fueled resistance to trade liberalization among organizations like NAM and the Chamber of Commerce. By the end of the 1980s, however, free trade advocates, primarily from large corporations, finally achieved a dominant (but not uncontested) position on the boards of these nominally small-business organizations, and the policy positions of both organizations changed noticeably.

Since 1990, both NAM and the Chamber of Commerce have endorsed virtually every major trade liberalization measure, including the North American Free Trade Agreement in 1993, establishment of the World Trade Organization in 1995, and permanent normal trade relations with China in 2000 (Shoch, 2001; Eckes, 2004; Destler, 2005). Typically this has involved the participation of both NAM and the Chamber of Commerce in lobbying coalitions with the moderate-conservative Business Roundtable. From the standpoint of official policy statements, there has thus been little difference between NAM and the Chamber on recent trade issues. However, the practical value of these policy statements to free trade advocates within the big business community has been vastly different. With fives times the budget of NAM and a membership of roughly 200,000 small businesses, the Chamber has become an indispensable ally in lobbying for the passage of free trade legislation, especially as big business has been forced to pursue a more "grassroots" lobbying strategy to turn the tide in favor of measures that initially faced majority opposition both within the electorate and among small businesses. NAM endorsement of the same legislation has not brought with it a comparable level of lobbying support and has often been accompanied by widespread grumbling and bitter internal struggles fomented by the protectionist bloc of domestic manufacturers that retains a much stronger voice within the leadership of NAM than within the Chamber of Commerce (McCormack, 2006a, 2006b). 
As the alliance between the Chamber of Commerce and free trade advocates has solidified, the pattern of the Chamber's interlocks has changed in tandem. In the 1970s the Chamber's strongest interlocks were with the National Association of Manufacturers. In the 1980s the Chamber's interlocks with NAM declined, while those with the Business Roundtable and other moderate-conservative policy groups increased. ${ }^{17}$ These trends accelerated in the 1990s as interlocks with NAM became even rarer, while interlocks with the Business Roundtable doubled from three to six. ${ }^{18}$ By comparison, throughout the 1980s and 1990s NAM rarely had more than a single interlock with the Business Roundtable or with any of the other moderate-conservative policy-planning groups.

Apart from shifts in the network position of individual organizations, the most dramatic change in the policy network during the period of this study was the sharp increase in the density of interlocks in the late 1970s and early 1980s, followed by an equally sharp decrease in the 1990s. Previous studies of this period have commented on the extraordinary degree of political unity achieved by economic elites in the late 1970s and early 1980s (Edsall, 1984; Ferguson \& Rogers, 1986; Akard, 1992). The increase in the density of the policy network in the late 1970s is therefore to be expected, insofar as the strength and breadth of board interlocks is generally understood as enhancing the potential for inter-organizational coordination and cohesion. On the other hand, the sharp decline in network density in the 1990s was not anticipated. The extent of that decline should not be exaggerated. Network density in the 1990s remained comparable to that of the early 1970s, but the unusually high cohesion of the early 1980s was not sustained. Several explanations can be given for this pattern.

At the most general level, historical research on corporate political action suggests that business political unity is likely to be most pronounced in those periods characterized by chronic or systemic constraints on capital accumulation (Prechel, 1990, 2000). During such periods, diverse segments of the business community have a stronger incentive to set aside competing interests and mobilize behind a common agenda for restructuring the political and institutional arrangements that constrain the accumulation of capital. This thesis is consistent with most narrative accounts of the mobilization of economic elites in the 1970s and early 1980s, which is commonly attributed to concerns over the decline of U.S. economic and geopolitical hegemony, the threat to corporate profitability posed by new environmental, consumer, and health and safety legislation, the fear of price controls and other government action to combat stagflation, and the perception of organized labor as an obstacle to outsourcing, capital mobility, and other economic restructuring.

On the other hand, the same historical research suggests that, to the extent that economic elites are successful in altering basic political and institutional arrangements so that conditions for capital accumulation become more favorable, the unity of the business community tends to decline, at least in relative terms. This does not mean that corporate elites cease to be politically active, but it does mean that corporate political action tends to revert to a more firm-specific or industry-specific set of policy priorities. This pattern has been noted, for example, in the research on corporate PAC contributions, which shows that corporate unity around an aggressively conservative, classwide strategy of contributing heavily to Republican challengers increased during the late 1970s and early 1980s, and then gradually tapered off in the mid- and late 1980 s as firms returned to a 
more pragmatic strategy of contributing mainly to incumbents for firm-specific purposes of political access (Su, Neustadtl, \& Clawson, 1995). It is thus plausible that corporate elites, who are the directors most responsible for creating interlocks between policyplanning organizations, may also have reassessed their priorities once the right turn in U.S. state policy was firmly established, and reduced their commitment to classwide initiatives aimed at altering the basic structure of capital-state relations. Having largely accomplished their goals of reducing the constraints of labor and the state on capital accumulation, businesses were freer to pursue their own interests. Corporate elites continued to dominate the boards of leading policy-planning organization; however, by the late 1980s or early 1990s, it appears that fewer of them were willing to pursue or accept the responsibilities of multiple directorships on policy boards.

In any historical period, the relationship between the conditions affecting capital accumulation and the prospects for business unity is likely to be somewhat contingent and mediated by the distinctive nature of existing institutional structures and extraneous forces of various kinds. During the late 1980s and 1990s several additional factors can be identified that may have contributed to a shift of corporate priorities toward firm-specific interests and away from intensive mobilization aimed at strengthening corporate cohesion through coordination among policy-planning organizations. The takeover wave of the 1980s served to shift the attention of corporate CEOs away from the long-term concerns of business as a whole and toward the short-term performance of their individual firms. During the same period a well-organized campaign on the part of large institutional investors began to monitor the performance of corporate officers and directors and press for changes in corporate governance (Useem, 1996). While this campaign was primarily focused on shareholder value, executive compensation, and board independence, another concern was the perception that corporate CEOs neglected their primary responsibility to firm growth and profitability by spending too much time on outside boards of directors. Such pressures may have led corporate elites to decline invitations to serve on multiple policy-planning boards. Also during this period, the power of large commercial banks over the flow of capital declined and bank boards ceased to serve the integrative function they provided in the 1960s and 1970s in mediating inter-industry conflicts and forging a classwide perspective (Davis \& Mizruchi, 1999). As noted by Burris (1992), roughly half the directors who created inter-organizational ties within the policy-planning network at the peak of its cohesion in 1980 also held a directorship on the board of one of the ten largest commercial banks. This suggests that bank boards of directors played a key role during that era in forging political consensus and grooming corporate elites for exercising classwide responsibilities in the policy-planning arena, and that subsequent changes in the composition and function of bank boards may have contributed to a weakening of cohesion among policy-planning elites and organizations. ${ }^{19}$

\section{CONCLUSION}

The findings of this study support the notion that director interlocks serve important functions in cementing political alliances and coordinating activities among policyplanning organizations. In contrast to the findings on corporate interlocking directorates, I found that interlocks among policy-planning groups are both substantively meaningful and relatively stable at the dyadic level, although several changes in the topology of the 
network were also found. In all three decades of the study, big-business "moderateconservatives" occupied the most central locations in the network. In the 1970s these organizations were linked with the "corporate liberals" to form the core cluster of the policy network. Over the course of the 1980s and 1990s the corporate liberals became relatively isolated from the core and their places were taken by several ultraconservative groups. Concurrent with this realignment, there was a sharp rise in the cohesion of the network in the late 1970s and 1980s - a period that is widely seen as one of conservative mobilization and increased political unity among economic elites followed by a decline in network cohesion in the 1990s. These changes in the policy network are consistent with and add to our understanding of the inter-organizational dynamics that facilitated the rightward shift in U.S. state policy during this period.

Apart from these specific findings, this study highlights the potential contribution that network analyses of interlocking directorates can make to the investigation of policyplanning organizations and processes. As I have shown, quantitative analyses of director interlock networks provide reasonably accurate maps of patterns of ideological alignment among policy-planning organizations (and historical shifts in those alignments) that are consistent with the results of more in-depth, qualitative studies of the same organizations. This lends credibility to the use of director interlock data for purposes of triangulation with qualitative studies as well as the independent use of interlock data for exploratory research or for studies in which more detailed information on the activities and alliances of policy-planning organizations is unavailable or unobtainable.

In this study I have mainly relied on documentary evidence of a qualitative sort to contextualize and interpret the patterns identified through formal methods of network analysis. Generally speaking, this documentary evidence tends to corroborate many of the expectations one might derive from the theoretical literature on the nature and functioning of social networks - for example, the expectation that network centrality tends to be associated with power or influence, that network proximity tends to be associated with similarity of belief or behavior, and that network density tends to be associated with intraclass or inter-organizational cohesion.

In many instances, there is no alternative or no better way of clarifying the implications and historical context of policy board interlocks than to draw upon (or to undertake) documentary research of this kind. Nevertheless, further progress in specifying the correlates and consequences of interlocking directorates within the policyplanning arena will likely depend, at least in part, on the construction of more exact and less subjective measures of the characteristics and actions of policy-planning organizations at specific points in time. More rigorous measures of this sort would allow for greater precision in specifying the causal significance of director interlocks among policy organizations, the temporal relationship between interlock patterns and changes in organizational behavior, and, potentially, the testing of more refined, multivariate models of the role that director interlocks play within the policy-planning process. More systematic and focused interviews with officers and directors of leading policy-planning organizations might also contribute important insights into this process.

Finally, director interlock research employing substantially larger samples of policy-planning organizations would be useful for corroborating, modifying, or extending 
the results of this study. The obstacles to gathering historical data on policy-planning board memberships, together with the continual entry of new organizations in to this domain, would likely necessitate a sample that was limited to one or several relatively recent years. This would curtail the possibility of addressing longitudinal questions over multiple decades. Nevertheless, a more encompassing study of the larger population of policy-planning groups - both large and small, old and new - would surely produce findings that go beyond anything one could reliably infer from the present study of “peak” policy-planning organizations.

\section{ACKNOWLEDGMENTS}

I wish to thank Harland Prechel and the anonymous reviewers for Research in Political Sociology for their thoughtful and detailed comments on this paper. An earlier version of the paper was presented at the Polities Workshop, sponsored by the Harriman Institute at Columbia University, April 2007.

\section{NOTES}

1. Unlike corporations and other types of nonprofits, policy-planning group interlocks were calculated on the basis of the entire membership of these organizations rather than only their boards of directors; however, Salzman and Domhoff's measure of centrality did control for variations in the size of organizations, so these results cannot be attributed simply to the large membership of some policy-planning groups.

2. The term distance here refers to geodesic distance - i.e., the shortest path or the fewest number of links required to get from one firm to another.

3. Board interlocks among policy groups were not the main focus of this study; however, Jenkins and Eckert (2000) did mention that organizations they classified as "moderate-conservative" often shared directors with both the "ultraconservative" and the “corporate liberal” policy-planning groups, whereas there were very few direct interlocks between the ultraconservative and corporate liberal organizations.

4. Eigenvector centrality is based on the number or strength of links possessed by each organization, where each link is, in turn, weighted by the centrality of the organization to which it connects.

5. Twelve organizations might seem like a relatively small sample for a study of director interlocks; however, there is a strong consensus in the literature on these twelve as exercising a degree of influence over the policy-planning process that places them in a category of their own. Among those who study policy-planning groups, any given researcher might wish to add one or two organizations to this category, but these would likely vary from one researcher to the next. Also, some of the most deserving candidates for addition to the sample (e.g., the Cato Institute or the Manhattan Institute) were not founded until the late-1970s, and there are substantive issues that are central to this study that require a sample going back to at least the early 1970s. Moreover, the practical obstacles to assembling a larger sample should not be underestimated. Unlike publicly 
traded corporations, policy-planning organizations are not legally required to reveal the names of their directors, and there are no readily available directories or databases that provide more than piecemeal information of this nature. Most such organizations are willing to make their board members' names public, but some are highly secretive, and, even among the former, requests for historical data may be denied because of the expense or difficulty involved in retrieving it. Assembling the data for this study required not only repeated correspondence with the organizations in the sample, but extensive archival research, as well as the assistance of journalists, Congressional staffers, and individuals associated with rival or watchdog organizations. For additional information on the histories and activities of these twelve organizations, see Burch (1983), Smith (1991), Burris (1992), Dye (2001), and Domhoff (2006).

6. Bonacich's measure is given by the formula $r=\left(n_{11} n_{22}-\left(n_{11} n_{22} n_{12} n_{21}\right)^{1 / 2}\right) /\left(n_{11} n_{22}\right.$ $-n_{12} n_{21}$, where $n_{11}$ is the number of members shared by the two groups, $n_{12}$ is the number of members in group 1 who are not in group $2, \mathrm{n}_{21}$ is the number of members in group 2 who are not in group 1 , and $\mathrm{n}_{22}$ is the number of individuals who are members of some group in the network but not of group 1 or group 2 . When $n_{11} n_{22}=n_{12} n_{21}, r$ is defined as equal to 0.5. Several previous studies have used this measure to control for variations in the size of policy-planning boards (Domhoff, 1975; Burris, 1992).

7. There are also a small number of liberal or left-liberal policy-planning organizations, but none of these compete in either resources or influence with the 12 policy groups included in this sample.

8. My use of the term “corporate liberal” is meant to be purely descriptive and should not be interpreted as taking a position one way or another on the more sweeping and much debated theory of "corporate liberalism," which entails a distinctive conception of capitalist class fractions and their role in initiating or opposing liberal policy reform.

9. Simply squaring the values of this ideological proximity matrix creates a kindred measure that gives relatively greater weight to the highest levels of ideological similarity. The correlation between this modified measure and the interlock matrices for the 1970s, 1980s, and 1990s were $r=0.577,0.558$, and 0.537 respectively $(p<0.001$ in all cases).

10. Correlations were computed between individual years, rather than between the average overlap scores for the three decades, because the latter are not statistically independent.

11. The chief exception to this generalization is the Hoover Institution, which has a very large board of trustees and appoints a number of big donors and other notables to virtual lifetime terms, often with only token responsibilities.

12. If one assumes that ties between ideologically similar organizations are more likely to represent a substantively meaningful relationship, whereas ties among ideologically divergent organizations are more likely to be coincidental, then there is modest evidence for this hypothesis. Of the multiple-tie dyads in this analysis, the 
average difference in the CRC ideological rankings between organizations was only 1.0. Of the single-tie dyads, the average difference in the CRC rankings was 1.9.

13. Data for 2004 and 2007, although they are not strictly comparable because of major restructurings affecting the governing boards of several organizations, suggest that the increased centrality of the Chamber of Commerce in 2000 is not an anomaly, but has remained roughly constant in subsequent years. These same data suggest that the dip in the centrality of the Committee for Economic Development in 2000 has also persisted.

14. Burris (1992) reported similar findings for the increase in network density during the late 1970s, but, because that study ended in 1990, it was unable to detect the equally sharp decline in network density during the 1990s.

15. Here it might be noted that the consensus of opinion among corporate interlock researchers is that ideological homophily does not play an important role in the selection of directors among large, publicly traded corporations, except in the trivial sense that most corporations and corporate elites are likely to be politically right-ofcenter (Mizruchi, 1992; Burris, 2005).

16. Despite this history of cooperation and formal coordination, observers have also noted a strong undercurrent of competition between these ideologically kindred organizations for members, contributors, and public visibility (Molotsky and Weaver, 1986). By all indications, the Chamber of Commerce has been the more successful party in this fraternal rivalry, while the National Association of Manufacturers has struggled with stagnant membership and festering divisions between its mostly big business leadership and its rank-and-file base of predominantly small and medium-sized firms.

17. Indeed, even prior to the trade wars of the 1990s, the Chamber of Commerce was moving toward a stronger linkage with the core cluster of moderate-conservative policy-planning groups. In Figure 2 one can see that the Chamber's position in the MDS map of interlock proximities in the 1980s was intermediate between NAM and the moderate-conservative core. The results of the hierarchical clustering analysis for that decade were fairly close in terms of whether the Chamber of Commerce should be grouped with NAM or with the moderate-conservative core.

18. In 2004 the Chamber of Commerce had seven interlocks with the Business Roundtable and in 2007 it had five.

19. As an illustration of the relationship between changes in the composition and function of bank boards and cohesion among the boards of leading policy-planning organizations, consider the example of Citicorp/Citigroup, which was the largest bank in the U.S. during most of the period of this study. In 1973, the Citicorp board included 6 directors who collectively occupied 7 seats on the boards of 3 of the policy-planning organizations in this study. In 1980, at the peak of the cohesion of the policy-planning network, the Citicorp board included 14 directors who collectively occupied 28 seats on the boards of 9 of these same policy groups. By 2000, the Citigroup board included only 4 directors who occupied 4 seats on the boards of 3 of these policy groups. 


\section{REFERENCES}

Akard, P. J. (1992). Corporate mobilization and political power: The transformation of U.S. economic policy in the 1970s. American Sociological Review, 57, 597-615.

Aldrich, H. E., \& Pfeffer, J. (1976). Environments of organizations. Annual Review of Sociology, 2, 79-105.

Allen, M. P. (1992). Elite social movement organization and the state: The rise of the conservative policy-planning network. In: G. Moore \& J. A. Whitt (Eds.), Research in politics and society, Volume 4, The political consequences of social networks (pp. 87-110). Greenwich, CT: JAI Press.

Barabasi, A. (2002). Linked: The new science of networks. Cambridge, MA: Perseus.

Barnes, R. C. (2006). Multiple affiliations within the corporate elite. Paper presented at the conference on politics and interlocking directorates, Barcelona, Spain.

Blumenthal, S. (1986). The rise of the counter-establishment. New York: Times Books.

Bonacich, P. (1972). Technique for analyzing overlapping memberships. In: H. L. Costner (Ed.), Sociological Methodology, 1972 (pp. 176-185). San Francisco: Jossey-Bass.

Borgatti, S. P., Everett, M. G., \& Freeman, L. C. (2002). Ucinet 6 for Windows: Software for social network analysis. Harvard, MA: Analytic Technologies.

Burch, P. H., Jr. (1983). The American establishment: Its historical development and major economic components. In: P. Zarembka (Ed.), Research in political economy, Volume 6 (pp. 83-156). Greenwich, CT: JAI Press.

Burris, V. (1992). Elite policy-planning networks in the United States. In: G. Moore \& J. A. Whitt (eds.), Research in politics and society, Volume 4, The political consequences of social networks (pp. 111-134). Greenwich, CT: JAI Press.

Burris, V. (2005). Director interlocks and political cohesion among corporate elites. American Journal of Sociology, 111, 249-283.

Burt, R. S., Christman, K. P., \& Kilburn, H. C., Jr. (1980). Testing a theory of corporate cooptation. American Sociological Review, 45, 821-841.

Clawson, D., \& and Clawson, M. A. (1987). Reagan or business: foundations of the new conservatism. In: M. Schwartz (Ed.), The structure of power in America (pp. 201217). New York: Holmes \& Meier.

Colwell, M. A. C. (1980). The foundation connection: Links among foundations and recipient organizations. In: R. F. Arnove (Ed.), Philanthropy and cultural imperialism (pp. 413-452). Bloomington: Indiana University Press.

Covington, S. (1997). Moving a public policy agenda: The strategic philanthropy of conservative foundations. Washington, DC: National Committee for Responsive Philanthropy. 
Davis, G. F. (1991). Agents without principles? The spread of the poison pill through the intercorporate network. Administrative Science Quarterly, 36, 583-613.

Davis, G. F., \& Greve, H. R. (1997). Corporate elite networks and governance changes in the 1980s. American Journal of Sociology, 103, 1-37.

Davis, G. F., \& Mizruchi, M. S. (1999). The money center cannot hold: Commercial banks in the U.S. system of corporate governance. Administrative Science Quarterly, 44, 215-239.

Davis, G. F., Yoo, M., \& Baker, W. E. (2003). The small world of the American corporate elite 1982-2001. Strategic Organization, 1, 301-26.

Destler. I. M. (2005) American trade politics. Washington DC: Institute for International Economics.

Domhoff, G. W. (1975). Social clubs, policy-planning groups, and corporations: A network study of ruling-class cohesiveness. Insurgent Sociologist, 5(3), 173-184.

Domhoff, G. W. (2006). Who rules America: Power, politics, and social change. New York: McGraw-Hill.

Dye, T. R. (1978). Oligarchic tendencies in national policy-making: The role of private policy-planning organizations. Journal of Politics, 40, 309-331.

Dye, T. R. (2001). Top-down policymaking. New York: Seven Bridges Press.

Eckes, A. E., Jr. (2004). U.S. trade history. In: W. E. Lovett, A. E. Eckes, Jr., \& R. L. Brindman (Eds.), U.S. trade policy: History, theory, and the WTO (pp. 36-92). Armonk, NY: M. E. Sharpe.

Edsall, T. B. (1984). The new politics of inequality. New York: W. W. Norton

Ferguson, T., \& Rogers, J. (1986). Right turn: The decline of the democrats and the future of American politics. New York: Hill \& Wang.

Haunschild, P. R. (1993). Interorganizational imitation: The impact of interlocks on corporate acquisition activity. Administrative Science Quarterly, 38, 564-592.

Himmelstein, J. L. (1990). To the right: The transformation of American conservatism. Berkeley: University of California Press.

Jenkins, J. C., \& Eckert, C. (2000). The right turn in economic policy: Business elites and the new conservative economics. Sociological Forum, 15, 307-338.

Koenig, T., Gogel, R., \& Sonquist, J. (1979). Models of the significance of interlocking corporate directorates. American Journal of Economics and Sociology, 38, 173-186

Kotz, D. M. (1978). Bank control of large corporations in the United States. Berkeley: University of California Press.

Levitan, S. A., \& Cooper, M. R. (1984). Business lobbies: The public good and the bottom line. Baltimore: Johns Hopkins University Press. 
Mace, M. L. (1971). Directors: Myth and reality. Boston: Harvard Business School.

McCormack, R. (2006a). Domestic manufacturers force the National Association of Manufacturers' big members to take a stand on China. Manufacturing and Technology News, July 7.

McCormack, R. (2006b). NAM board votes in favor of multinationals in debate over China’s currency. Manufacturing and Technology News, October 10.

Mintz, B., \& Schwartz, M. (1985). The power structure of American business. Chicago: University of Chicago Press.

Mizruchi, M. S. (1992). The structure of corporate political action. Cambridge: Harvard University Press.

Mizruchi, M. S. (1996). What do interlocks do? An analysis, critique, and assessment of research on interlocking directorates. Annual Review of Sociology, 22, 271-298.

Mizruchi, M. S., \& Stearns, L. B. (1994). A longitudinal study of borrowing by large American corporations. Administrative Science Quarterly, 39, 118-140.

Molotsky, I., \& Weaver, W., Jr. (1986). Briefing: Popular speaker. New York Times, September 10, B6.

Moore, G., Sobieraj, S., Whitt, J. A., Mayorova, O., \& Beaulieu, D. (2002). Elite interlocks in three U.S. sectors: Nonprofit, corporate, and government. Social Science Quarterly, 83, 726-744.

Ornstein, M. (1982). Interlocking directorates in Canada: Evidence from replacement patterns. Social Networks, 4, 3-25.

Palmer, D. (1983). Broken ties: Interlocking directorates and intercorporate coordination. Administrative Science Quarterly, 28, 40-55.

Palmer, D., Jennings, P. D., \& Zhou, X. (1993). Late adoption of the multidivisional form by large U.S. corporations. Administrative Science Quarterly, 38, 100-131.

Pennings, J. M. (1980). Interlocking directorates. San Francisco: Jossey-Bass.

Peschek, J. G. (1987). Policy-planning organizations: Elite agendas and America's rightward turn. Philadelphia: Temple University Press.

Pfeffer, J., \& Salancik, G. R. (1978). The external control of organizations: A resource dependence perspective. New York: Harper \& Row.

Prechel, H. (1990). Steel and the state: Industry politics and business policy formation, 1940-1989. American Sociological Review, 55, 648-668.

Prechel, H. (2000). Big business and the state. Albany, NY: State University of New York Press. 
Rao, H., Davis, G. F., \& Ward, A. (2000). Embeddedness, social identity, and mobility: Why firms leave the NASDAQ and join the New York stock exchange. Administrative Science Quarterly, 45, 268-292.

Salzman, H., \& Domhoff, G. W. (1983). Nonprofit organizations and the corporate community. Social Science History, 7, 205-16.

Shoch, J. (2001). Trading blows: Party competition and U.S. trade policy in a globalizing era. Chapel Hill: University of North Carolina Press.

Smith, J. A. (1991). The idea brokers: Think tanks and the rise of the new policy elite. New York: Free Press.

Su, T., Neustadtl, A., \& Clawson, D. (1995). Business and the conservative shift: Corporate PAC contributions, 1976-1986. Social Science Quarterly, 76, 20- 40.

Useem, M. (1984). The inner circle. New York: Oxford University Press.

Useem, M. (1996). Investor capitalism: How money managers are changing the face of corporate America. New York: Basic Books

Vogel, D. (1989). Fluctuating fortunes: The political power of business in America. New York: Basic Books.

Watts, D. J. (2004). The 'new' science of networks. Annual Review of Sociology, 30, 243-270.

Yablonski, C. (2001). Patterns of corporate philanthropy. Washington, DC: Capital Research Center.

Zajac, E. J., \& Westphal, J. D. (1996). Director reputation: CEO-board power and the dynamics of board interlocks. Administrative Science Quarterly, 41, 507-529.

Zeiler, T. W. 1992. American trade and power in the 1960s. New York: Columbia University Press. 
ORGANIZATIONS

\begin{tabular}{|c|c|c|c|c|c|c|c|c|c|c|c|}
\hline & & & & & & $970 \mathrm{~s}$ & & & & & \\
\hline BC & .21 & & & & & & & & & & \\
\hline BI & .00 & .15 & & & & & & & & & \\
\hline BRT & .19 & .76 & .14 & & & & & & & & \\
\hline CB & .16 & .56 & .44 & .63 & & & & & & & \\
\hline CC & .10 & .00 & .09 & .18 & .09 & & & & & & \\
\hline CED & .39 & .34 & .30 & .34 & .41 & .20 & & & & & \\
\hline CFR & .00 & .00 & .47 & .27 & .12 & .09 & .20 & & & & \\
\hline $\mathrm{HF}$ & .16 & .00 & .00 & .13 & .00 & .11 & .00 & .00 & & & \\
\hline HI & .42 & .38 & .00 & .26 & .21 & .00 & .06 & .00 & .30 & & \\
\hline NAM & .00 & .00 & .00 & .11 & .00 & .32 & .00 & .00 & .00 & .19 & \\
\hline \multirow[t]{2}{*}{$\mathrm{TC}$} & .00 & .00 & .60 & .14 & .00 & .00 & .42 & .66 & .00 & .00 & .00 \\
\hline & AEI & BC & BI & BRT & CB & CC & CED & CFR & $\mathrm{HF}$ & HI & NAM \\
\hline \multicolumn{12}{|c|}{$1980 \mathrm{~s}$} \\
\hline BC & .66 & & & & & & & & & & \\
\hline BI & .00 & .43 & & & & & & & & & \\
\hline BRT & .50 & .69 & .31 & & & & & & & & \\
\hline CB & .54 & .55 & .29 & .62 & & & & & & & \\
\hline CC & .10 & .00 & .09 & .29 & .33 & & & & & & \\
\hline CED & .39 & .46 & .35 & .42 & .41 & .23 & & & & & \\
\hline CFR & .14 & .41 & .47 & .44 & .25 & .30 & .24 & & & & \\
\hline HF & .16 & .00 & .00 & .13 & .00 & .24 & .00 & .00 & & & \\
\hline $\mathrm{HI}$ & .40 & .11 & .00 & .19 & .00 & .06 & .06 & .21 & .53 & & \\
\hline NAM & .00 & .00 & .00 & .31 & .00 & .23 & .00 & .00 & .00 & .00 & \\
\hline \multirow[t]{2}{*}{ TC } & .00 & .00 & .57 & .14 & .00 & .00 & .13 & .62 & .00 & .00 & .00 \\
\hline & AEI & BC & BI & BRT & CB & CC & CED & CFR & $\mathrm{HF}$ & HI & NAM \\
\hline \multicolumn{12}{|c|}{$1990 \mathrm{~s}$} \\
\hline BC & .60 & & & & & & & & & & \\
\hline BI & .00 & .14 & & & & & & & & & \\
\hline BRT & .46 & .70 & .17 & & & & & & & & \\
\hline CB & .18 & .33 & .00 & .53 & & & & & & & \\
\hline CC & .00 & .12 & .09 & .26 & .13 & & & & & & \\
\hline CED & .14 & .17 & .24 & .33 & .25 & .18 & & & & & \\
\hline CFR & .00 & .41 & .48 & .43 & .13 & .11 & .38 & & & & \\
\hline $\mathrm{HF}$ & .00 & .00 & .00 & .00 & .00 & .00 & .00 & .00 & & & \\
\hline HI & .14 & .00 & .00 & .11 & .00 & .00 & .00 & .17 & .52 & & \\
\hline NAM & .00 & .00 & .00 & .35 & .00 & .09 & .00 & .00 & .00 & .00 & \\
\hline \multirow[t]{2}{*}{ TC } & .00 & .00 & .17 & .00 & .00 & .00 & .00 & .66 & .00 & .00 & .00 \\
\hline & AEI & BC & BI & BRT & CB & CC & CED & CFR & $\mathrm{HF}$ & $\mathrm{HI}$ & NAM \\
\hline
\end{tabular}

Key: $\mathbf{A E I}=$ American Enterprise Institute $\mathbf{B C}=$ Business Council; $\mathbf{B I}=$ Brookings Institution; $\mathbf{B R T}=$ Business Roundtable; $\mathbf{C B}=$ Conference Board; $\mathbf{C C}=$ Chamber of Commerce; $\mathbf{C E D}=$ Committee for Economic Development; CFR = Council on Foreign Relations; HF = Heritage Foundation; $\mathbf{H I}=$ Hoover Institution; NAM = National Association of Manufacturers; TC $=$ Trilateral Commission . 
APPENDIX B. HIERARCHICAL CLUSTERING OF POLICY-PLANNING

\section{ORGANIZATIONS}
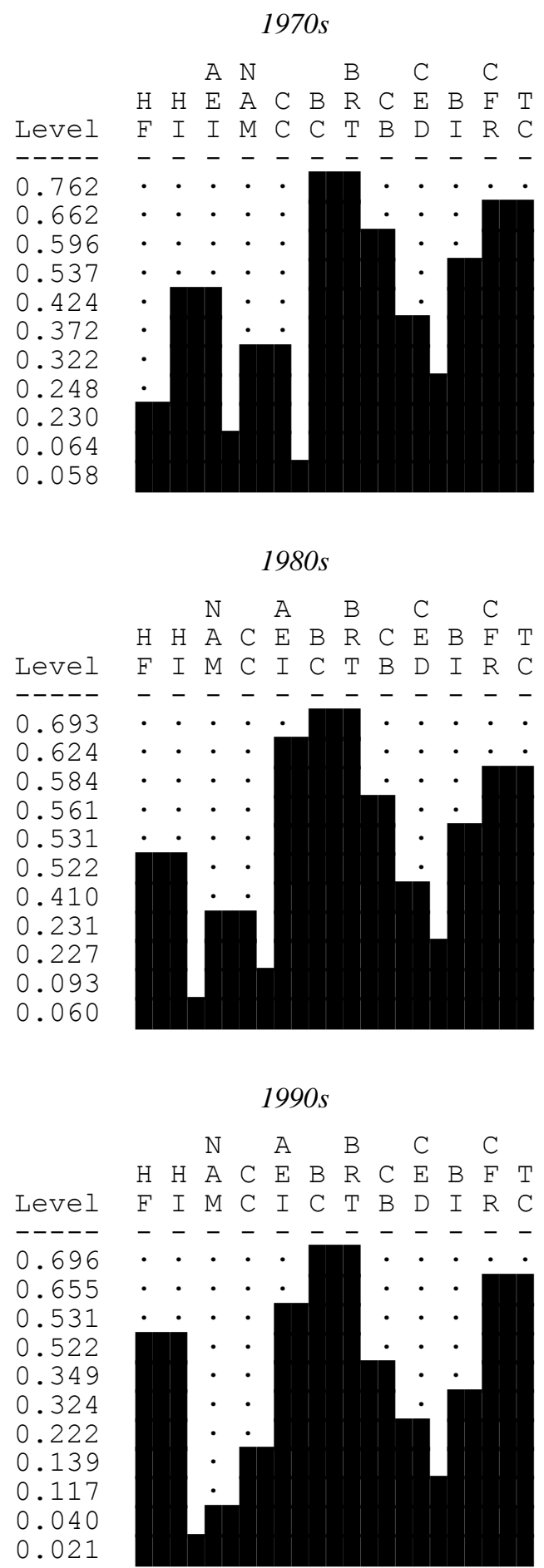

Key: $\mathbf{A E I}=$ American Enterprise Institute; $\mathbf{B C}=$ Business Council; $\mathbf{B I}=$ Brookings Institution; $\mathbf{B R T}=$ Business Roundtable; $\mathbf{C B}=$ Conference Board; $\mathbf{C C}=$ Chamber of Commerce; $\mathbf{C E D}=$ Committee for Economic Development; CFR = Council on Foreign Relations; $\mathbf{H F}=$ Heritage Foundation; $\mathbf{H I}=$ Hoover Institution; NAM = National Association of Manufacturers; TC = Trilateral Commission. 